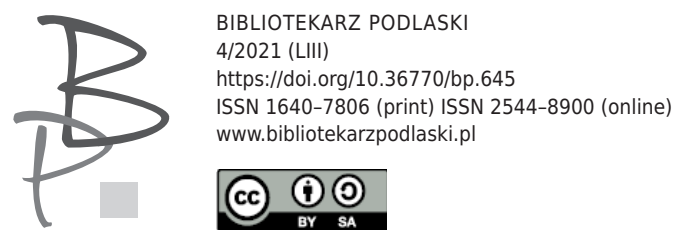

Violetta Wejs-Milewska*

Uniwersytet w Białymstoku, Polska / University of Białystok, Poland

ORCID: 0000-0002-1275-5369

\title{
Prolegomena do „wielkiej samotności”. Z listów Kazimierza Wierzyńskiego i Romana Palestra
}

\author{
Prolegomena to "the great loneliness". From the letters \\ of Kazimierz Wierzyński and Roman Palester
}

\begin{abstract}
The correspondence between Kazimierz Wierzyński and Roman Palester includes more than a hundred letters covering the years 1946-1969, referring to the uncomfortable position of Wierzyński as an emigrant and Palester intent on political emigration, hoping for the help of Poles based in European and American cultural institutions. The correspondence also precedes the personal meeting of the two creators, and its content concerns a wide range of vital problems related to staying outside Poland as well as writing about, composing, experiencing loneliness and personal experiences of intimate nature. The letters under discussion contain opinions on the artistic environment at home and in the world as well as interesting and significant remarks on politics and culture.
\end{abstract}

Keywords: epistolography, emigration, ego-documents, history of music.

* Violetta Wejs-Milewska - prof. dr hab., literaturoznawczyni, kierownik Katedry Filologicznych Badań Interdyscyplinarnych (Uniwersytet w Białymstoku); autorka m.in. monografii Buenos Aires-Gwatemala-Montevideo-Nowy Jork-Paryz. Listy do Jana Nowaka-Jeziorańskiego i innych (2018). 
Emigracyjne doświadczenie wielowymiarowego wykluczenia i alienującej samotności czy duchowej odrębności znalazło swoją egzemplifikację w szczęśliwie zachowanej korespondencji, jaką przez wiele lat prowadzili między sobą dwaj wybitni polscy twórcy: poeta Kazimierz Wierzyński i kompozytor Roman Palester. Ponadto zachowany korpus listów, o którym będzie tu mowa, obejmujący lata 1946-1969 stanowi nawet dla badaczy XX-wiecznej emigracji1', znakomicie zorientowanych w meandrach fenomenu wychodźczego, jak i kultury tworzonej przez Polaków poza granicami kraju, pewną niespodziankę.

Chodzi o kilka kwestii, o których wypada pokrótce wspomnieć; ta pierwsza, narzucająca się niejako bezpośrednio, odnosi się do asymetrycznej relacji respondentów, szczególnie u zarania znajomości. Jednym z nich bowiem jest wybitny i uznany poeta - Kazimierz Wierzyński, drugim zaś Roman Palester o pokolenie młodszy kompozytor, choć mający już na swoim koncie znaczące sukcesy międzynarodowe.

Kariera Palestra znakomicie rozpoczęta w latach 30. ubiegłego stulecia, wskutek wybuchu wojny znacząco wyhamowała, by w pierwszych latach po-

1 Korespondencja Wierzyńskiego i Palestra aktualnie gromadzona jest w jeden korpus dzięki kwerendom w archiwach w Polsce i zagranicą [tj. m.in. BUW, Biblioteka Polska w Londynie, Biblioteka Polska w Paryżu]; do tej pory udało się zgromadzić 71 listów Wierzyńskiego do Palestra i 36 Palestra do Wierzyńskiego. Przy okazji należy podkreślić, że zarówno aktywność epistolograficzna Wierzyńskiego, jak i Palestra, jest bardzo duża i z pewnością listy obu autorów do innych respondentów zasługują na osobne opracowanie oraz ogłoszenie drukiem. Oba nazwiska w centrum epistolografii dają gwarancję na odtworzenie niezwykle interesujących związków Polaków z wybitnymi postaciami europejskiej i transatlantyckiej kultury (gros z nich łączyła Galicja). Pozwoli to również - w przypadku Wierzyńskiego - na głębsze zapoznanie jego twórczych motywacji, czy też pogłębioną heurezę życia, w tym oświetlenie spraw mało znanych; korespondencja stanowić winna również podstawę dla rekonstrukcji pełnej biografii życia i twórczości poety, na którą wciąż niestety czekamy. Dotychczas ukazała się niewielka część tej korespondencji (dodajmy, że chodzi najczęściej o listy odręczne i pismo sprawiające ogromny kłopot edytorski), m.in. Listy Kazimierza Wierzyńskiego do Józefa Wittlina, „Więź” 1989, nr 2; J. Lechoń, K. Wierzyński, Listy 1941-1956, Warszawa 2016. Palester z kolei oczekuje na pełną edycję epistolograficzną i publicystyczną. Powstały jak dotąd dwie monografie Palestra jako kompozytora, zob. Z. Helman, Roman Palester. Twórczość i dzieło, Kraków 1999 oraz L. Dzierżanowski, Palester. Kraków 2021.

Na podkreślenie zasługuje również fakt, że spora część wzmiankowanej w moim szkicu korespondencji przypada na późne lata 40. i 50. XX wieku, czyli na okres najciekawszy - tuż powojenny, obarczony najtrudniejszymi wyborami, z niewykrystalizowaną sytuacją geopolityczną. 
wojennej Polski - powrócić na fali rosnącego zainteresowania rewitalizacją kultury narodowej. Ten krótki, choć znaczący moment - mimo symptomów czy pozorów systematycznego dźwigania z gruzów wielu dziedzin życia społeczno-kulturalnego, odbudowy zrównanych z ziemią instytucji wzmacniających polski prestiż, powołania do życia nowych - kompozytor starał się wykorzystać możliwie najpełniej. Ostatecznie jednak napotkał na bariery nie do przekroczenia, które między innymi wiązały się z radykalnie i totalnie zarządzoną socrealistyczną rewolucją w sferze kultury, odwracającą w skutkach najwcześniejsze spontaniczne inicjatywy krajowego środowiska artystycznego, którego Palester był aktywnym i uznanym przedstawicielem.

Obu respondentów ponadto dzieli znaczna (bo 13-letnia) ${ }^{2}$ różnica wieku, także rodzaj i skala dorobku, również intensywność rezonowania tej twórczości w międzywojniu i tuż po drugiej wojnie światowej. Ale są i podobieństwa, choć te ujawnią się sukcesywnie w miarę zaglądania do kulisów osobistego życia respondentów. Listy Wierzyńskiego i Palestra jednak, poza walorami o charakterze poznawczym (informacyjnym), poza przyjemnością obcowania ze swobodą ocen, z oryginalnymi sądami o ludziach i świecie, są cenne badawczo, ponieważ potwierdzają fakt istnienia epistolograficznych, dyskrecjonalnych relacji między emigracją a krajem; korespondencja ta staje się zatem kolejną nicią wplecioną w sieć takich właśnie kontaktów, o których ciągle niestety wiemy zbyt mało.

W tym konkretnym przypadku interesujące jest to, że emigrant ,zza wielkiej wody” - Kazimierz Wierzyński wymienia się listami póki co z „oficjalnym” obywatelem PRL-u, czasowo przebywającym za granicą, będącym jednak mentalnie - jak się z czasem okaże - co najmniej od 1946 roku emigrantem (egzulem) - Romanem Palestrem³. Ostatecznie z końcem 1949 roku Palester wyruszy śladami starszego kolegi, by ostatecznie odmienić swój sta-

2 Kazimierz Wierzyński (1894-1969); Roman Palester (1907-1989).

3 Roman Palester - kompozytor, historyk sztuki, komentator kulturalny (kierownik działu kulturalnego Radia Wolna Europa w latach 1952-1972), pisarz; wielokrotnie nagradzany jako kompozytor, aktywny w środowisku muzycznym do wojny, a po jej zakończeniu od 1947 roku czasowo przebywający poza Polską, emigrant od jesieni 1949 roku; kompozycje Palestra charakteryzuje zindywidualizowany język harmoniczno-brzmieniowy, polifonia i serializm; tworzył utwory orkiestralne, kameralne, muzykę fortepianową, teatralną radiową i filmową. Autor Stuchu absolutnego. Niedokończonej autobiografii i listów z lat wojny, w opracowaniu Z. Helman, Warszawa-Kraków 2017. 
tus i stać się emigrantem rzeczywistym. Ale nim to się dokona, kompozytor wykorzysta wszystkie wyjazdy służbowe na Zachód, by sondować możliwości owego przejścia na „drugą”, demokratyczną stronę świata. Listy będą dlań $\mathrm{w}$ istocie najbezpieczniejszym instrumentem, który sprawi, że cel ten stanie się w końcu możliwy do osiągnięcia.

Świadectwo dyskrecjonalne (a jest nim przecież list) - jest tym wartościowsze, że dokumentuje stosunkowo szczerą wymianę myśli między osobami, które darzą się wysokim stopniem zaufania, co pozwala nam zajrzeć pod podszewkę trudnych decyzji, zwłaszcza o charakterze motywacyjnym i intencjonalnym. Respondenci również (co nietrudno zauważyć już w pierwszym liście Palestra) mimo oczywistych biograficznych różnic są ideowo, mentalnie i duchowo bardzo sobie bliscy... Mimo geograficznego oddalenia, łączy ich bowiem nie tylko tęsknota do świata, który starła w pył wojna, ale i szczególny hart ducha, postawa trudnego aktywizującego pesymizmu, pozwalającego trwać mimo wszystko i oczekiwać zmian oraz zmiany te kreować.

Wybrzmiewa w listach raz między wierszami, raz dosłownie szeroka gama wspomnianych odczuć, choć przede wszystkim poza zagubieniem i strwożeniem dominuje w nich uczucie wielkiej samotności - samotności międzyludzkiej, „międzypolskiej” i twórczej, choć - co ciekawe - w zapisach Palestra odczuwa się tę samotność intensywniej. Pojawia się też - dominująca zwłaszcza w refleksji kompozytora - konceptualizacja znaczenia granicy jako linii wyraźnie ingerującej w wertykalny wymiar bytu, jako linii dzielącej, rozrywającej w istocie światy, które niegdyś były integralne, i linii wartościującej kultury. Granica tak rozumiana silniej też pozycjonuje Palestra po jednej ze stron ideowego sporu (a dowodzą tego jego późniejsze wypowiedzi publicystyczne) ${ }^{4}$. Ma też kompozytor głębokie przekonanie o przynależności do wspólnoty doświadczonej traumatycznie bez względu na polityczne, ideowe i geostrategiczne podziały, stąd świadomość istnienia owej trudnej do zaakceptowania zony, wyznaczającej strefy dominacji i dzielącej zbiorowość na „My” i „Wy”.

„My” - to krajowcy, Polacy z PRL-u, „Wy” - emigracja. Ów sztuczny, choć dokonany realnie podział wprawia Palestra w irytację, która właściwie nie mija do końca jego życia, co najwyżej z czasem nieco słabnie. Pozycjonowanie zmienia się też wraz ze zmianą „miejsca postoju” samego responden-

4 Mowa o bogatej publicystyce radiowej w Radiu Wolna Europa (ponad tysiąc zachowanych skryptów). 
ta; gdy autor Śmierci don Juana znajdzie się oficjalnie po zachodniej stronie świata, zaimek rzeczowny „My” będzie w jego publicystyce obsługiwał wychodźstwo, a więc i jego samego, natomiast „Wy” - to adresaci krajowi, koledzy z branży muzycznej, którzy w Polsce pozostali i w niej pracują.

Odtąd też uzna, że opowiadanie się po stronie niemających dostępu do agory wolnego słowa kolegów-kompozytorów winno stać się główną osią jego emigracyjnej misji, którą będzie z uporem wypełniał przez dwadzieścia lat swojej pracy w Rozgłośni Polskiej Radia Wolna Europa w Monachium. Listy do Wierzyńskiego (i do innych respondentów z rozległego korpusu epistolarnego Palestra ${ }^{5}$ ujawniają też etapowość dojrzewania do decyzji o ostatecznym opuszczeniu Polski: najpierw bowiem wyjeżdża - zapewne po raz pierwszy - w 1946 roku do Londynu na Festiwal Międzynarodowego Towarzystwa Muzyki Współczesnej, gdzie grany jest jego Koncert skrzypcowy (pisany w latach 1939-1941) i korzystając z okazji pobytu poza krajem, z hotelu - 6 sierpnia pisze najprawdopodobniej swój pierwszy list do Wierzyńskiego:

Kochany i tyle bliski Panie Kazimierzu,

nie mogę sobie odmówić przyjemności skreślenia paru słów do Państwa, jeżeli można nazwać przyjemnością to, że jesteście gdzieś tak okropnie daleko od nas i od kraju...

Dostałem korektę Pańskiego ostatniego tomu' ${ }^{6}$, przeczytałem mniej więcej wszystko co Pan w czasie wojny napisał i jestem tak wstrząśnięty, tak głęboko przejęty sposobem i tonem, w którym Pan daje świadectwo wszystkich klęsk polskich naszego pokolenia, że pragnę Panu za pomocą tych kilku niezdarnych słów przenośnie „uścisnąć rękę” i przesłać najczulsze pozdrowienia od wielu, wielu, którzy w dość rozmaitych warunkach obcować będą z Pańską poezją.

Żyjemy zaiste w czasach „wielkiej samotności”, kiedy istotne i najgłębsze rzeczy dokonują się w najdalszym i największym oddaleniu od swojej gleby i swego „klimatu”. Myślę, że wie Pan co chcę powiedzieć i że zostanie Pan

5 Kompozytor był aktywnym respondentem; zasób epistolarny dotychczas zidentyfikowany i po części przebadany to setki listów i kilkudziesięciu nadawców: kompozytorów, dyrygentów, muzykologów, pisarzy, teatrologów, wydawców, członków rodziny.

6 Chodzi o tom wierszy Krzyże i miecze (1946). Prawdopodobnie otrzymał do lektury tom w przygotowaniu do wydania, co z kolei pozwala sądzić, że kontakty Palestra z emigracją od samego początku były ścisłe. 
naszym przyjacielem, tak jak my wszyscy jesteśmy przyjaciółmi Państwa. Zdajemy też sobie sprawę z Waszych bólów i tragedii, tak jak pewno i Wy z naszych...

Za parę dni wracamy do kraju; w jesieni może uda się nam pojechać na jakiś czas do Paryża - wtedy znów napiszemy - nie sądzę żeby do tej pory wiele się zmieniło na tym najlepszym ze światów! Gdy tylko więcej moich utworów będzie wydrukowanych (między innymi II Symf.7) pozwolę sobie to wszystko przesłać do Ameryki, może na coś się przyda, może Rodziński ${ }^{8}$ albo kto inny się zainteresuje. Tu w Londynie powiodło się nam wcale nieźle ale możliwości na dłuższe zahaczenie się nie ma...

Ciekawi jesteśmy życia za „wielką wodą”, czy warto je poznać ?...

[...] W każdym razie jesteśmy pewni, że jeszcze się z Państwem zobaczymy w jakichś znośnych warunkach9.

Jeżeli przyjmiemy, że rzeczywiście mamy tu do czynienia z fragmentem pierwszego listu Palestra do Wierzyńskiego, to musimy przyznać jego nieoczywisty charakter. Zwłaszcza zaskakuje ciepła tonacja, jak i wyraźne skrócenie dystansu między respondentami, usprawiedliwione tylko w wypadku osobistej znajomości. A tej nie można potwierdzić. W zgromadzonym korpusie epistolarnym Wierzyński - Palester list z 1946 roku jest najwcześniejszy, ale nie mamy pewności, czy nie poprzedzał go inny, do którego nie było nam dane dotrzeć lub po prostu nie zachował się? Dlaczego jednak pisze Palester z Londynu do Wierzyńskiego, a nie do innego twórcy z emigracji? Nie mamy i na to pytanie dobrej odpowiedzi. Być może zdecydował „wstrząs lekturowy” i silne poczucie wspólnotowe, które znalazło swój wyraz w wojennej poetyce tomu wierszy Wierzyńskiego Krzyże i miecze.

Analizując ten fakt z pozycji pragmatycznych, trzeba dodać, że w sprawach istotnych dyskrecjonalne wzajemne polecanie osób (respondentów)

7 II Symfonia (1942).

8 Artur Rodziński (1894-1958) - doktor prawa, dyrygent Opery Lwowskiej, Opery i Filharmonii Warszawskiej; od 1926 roku za granicą dyrygował m.in. Orkiestrą Filadelfijską, Nowojorską, Chicagowską. Wykonywał dzieła kompozytorów zachodnich i polskich, tj.: Moniuszki, Karłowicza i Szymanowskiego.

9 List Romana Palestra do Kazimierza Wierzyńskiego z 6 VIII 1946 [zbiory nieopracowane, nr akcesji 7221/1-2 - Biblioteka Polska w Paryżu]. 
było na porządku dziennym. Była to dobrze pojmowana protekcja. Wierzyński i Palester osobiście nie znali się do wybuchu wojny, co pośrednio wynika z niedokończonych wspomnień samego kompozytora - Sluch absolutny ${ }^{10}$. Łączyła ich za to ziemia lwowska, która stanie się jednym z powtarzających się stałych motywów późniejszych listów ${ }^{11}$. Być może również należy tłumaczyć owo ciepło płynące ze strony Palestra poczuciem wspólnoty „krajan”, o którą i łatwiej w czasach trudnych? W okresie okupacji drogi twórców również się nie przecięły: Palester przebywał w Warszawie, doświadczył terroru bezpośrednio jako więzień Pawiaka, Wierzyński natomiast po wybuchu wojny niezwłocznie opuścił Polskę, by od 1945 roku z żelazną konsekwencją dzielić los emigranta politycznego w USA, a u samego schyłku życia - w Anglii.

Palester skorzystał więc w 1946 roku z pobytu w Londynie, by bezpiecznie nadać korespondencję do Wierzyńskiego (wysyłka spoza Polski dawała gwarancję dotarcia do adresata, i ponadto pełną dyskrecję). W Londynie kompozytor przebywał służbowo, jednak nie zapominajmy, że pojawił się tam w charakterze oficjalnego przedstawiciela polskiej kultury krajowej: także w roli profesora krakowskiej Państwowej Wyższej Szkoły Muzycznej, prorektora z wyboru tej uczelni, jednego z najwybitniejszych kompozytorów XX-wiecznej muzyki klasycznej, filmowej i rozrywkowej (a najwybitniejszego w swoim pokoleniu). Być może ta osobista pozycja, jaką Palester zajmował już w środowisku, ośmieliła do zaskakująco prostolinijnego i zarazem eleganckiego epistolarnego wywodu. Być może nie tyle osobiste dokonania zawodowe ośmieliły go, ile poczucie wspólnoty doświadczenia.

Ludzie, których los boleśnie doświadcza (doświadczył), mają owe szczególne poczucie duchowej więzi, która nie tylko sprawia, że skraca się dystans, ale i zawiązuje się przyjaźń. I jak się wydaje, z takim przypadkiem mamy tu do czynienia. Przyjaźń obu respondentów trwała do śmierci Wierzyńskiego, do końca też była żywa i uczciwa, co potwierdzają listy. Początkowo kierowane do starszego kolegi prośby Palestra o pomoc dominowały nad innymi tematami,z czasem fluktuowały w swobodny, impresyjno-sentymentalny wywód. Jego kodę wyznaczały pytania praktyczne i egzystencjalne zarazem, 
na przykład: kiedy następna przeprowadzka? Albo: czy my wszyscy już nigdy nie będziemy mieszkać u siebie? Albo konstatacja: ale to właśnie na tym polega uchodźstwo... Irytację z lat 40 . w późniejszych listach zastępuje rzeczowa wymiana informacji o pracy własnej, o środowisku oraz coraz wyraźniej wybrzmiewa nuta melancholii, niepozbawiona kolorytu lokalnego wspomnienia. Jednocześnie sarkazmem i humorem podszyte są wzmianki o stanie zdrowia.

Będąc niepewnym losu listu sprzed pół roku, Palester skreśla kolejny, korzystając z okazji ponownej wyprawy na Zachód, tym razem do Paryża. W nim rozwija myśl, nieśmiało wybrzmiewającą $\mathrm{w}$ poprzednim, zasugerowaną enigmatycznym pytaniem: „...ciekawi jesteśmy życia za «wielką wodą», czy warto je poznać?...” ${ }^{\prime 2}$. Wbrew temu, co będzie jego autor mówił publicznie w latach 80 , poważnie rozważał emigrację do USA, w czym Wierzyński zdawał się być mu pomocny. Trzeba przyznać na marginesie, że poeta bardzo się w tę sprawę angażował. Uruchomił własne kontakty amerykańsko-polonijno-emigracyjne, choć nie okazały się one skuteczne. Palester bowiem do Ameryki oczywiście nie wyjechał, ale starania Wierzyńskiego mogły być pomocne w zdobyciu angażu w Wolnej Europie. Ale w listach poety do kompozytora ujawnia się rozległa sieć związków osobistych Wierzyńskiego $^{13}$ z Polakami (i nie tylko) osiadłymi na kontynencie amerykańskim. Respondent tym samym potwierdza istnienie imponującej konstelacji wybitnych przedstawicieli polskiego wychodźstwa, jaka tworzyła się wokół Wierzyńskiego i emigracji wojennej; łączyła ich wszystkich idea kultury jako wartości niezbywalnej, konsens co do wagi kontynuacji pracy twórczej i politycznej poza Polską dla jej najlepiej pojmowanych interesów. Istotnym spoiwem - mimo różnic - była również niechęć, a nawet wrogość do PRL-owskiego reżimu i jego akolitów.

W kolejnym liście Palester pisze tym razem otwarcie o swoich emigracyjnych planach:

12 Równocześnie od 1947 r. Palester w tej samej sprawie koresponduje m.in. z Jerzym Fitelbergiem, w treści listów wymieniany jest m.in. Wierzyński [Kolekcja Romana Palestra w „Archiwum Kompozytorów Polskich XX wieku” - BUW].

13 Korespondencja Wierzyńskiego jest imponująca, to tysiące zapisów do różnych adresatów. Jej w miarę pełne wydanie pozwoliłoby przywrócić recepcji autora zdecydowanie najmniej znany wymiar aktywności. 
Drogi Panie Kazimierzu,

wyrwaliśmy się na krótko do Paryża, korzystam więc z okazji, aby do Kochanego Pana parę słów skrobnąć. Nie wiem czy otrzymał Pan list, który wysłałem do Pana latem z Londynu, po przeczytaniu Pańskiego ostatniego tomu ${ }^{14}$; jeśli nie, to pragnę jeszcze raz wyrazić jak bardzo głęboko i bez reszty wypowiedział Pan to wszystko, co nam bardzo leży na sercu! Dla mnie ten tom był wstrząsającym przeżyciem i trzeba było zaiste dopiero obecnych czasów, abyśmy się doczekali, że poezji zabrania się wstępu w granice pewnych państw i że tom liryki może być nieprawomyślny.

Nie potrzebujemy Panu pisać jak żyjemy, wie Pan o tym zdaje się dość dobrze. Najszkodliwsze w tym wszystkim jest to, że sytuacja materialna artystów jest na ogół biorąc dość dobra. Oczywiście i to ludzi wypacza, a poza tym najbardziej tragiczny jest ten olbrzymi balast blagi i oszustwa, w którym przyszło nam żyć. Wyjazdy zagraniczne stają się coraz trudniejsze, dlatego też postaraliśmy się z żoną wyrwać się raz jeszcze na "Zachód” i próbować szukać gdzieś indziej pastwiska...

Niestety tutaj nie ma dużych możliwości, poza tym i Francji grozi gabinet komunistyczny, a przy tutejszych nastrojach wszelka możliwość jakiegoś „urządzenia się" choćby najskromniejszego odpada. Dlatego byłbym kochanemu Panu niezmiernie zobowiązany, gdyby Pan był łaskaw odpisać mi, czy nie ma jakichś możliwości zahaczenia się w U.S. i czy ostatecznie kompozytor muzyki poważnej może tam dać jakoś radę?

Czy można by liczyć na jakieś poparcie Polonii amerykańskiej, no i czy w ogóle pozwolono by nam wjechać do Stanów? Oczywiście, to wszystko tylko tytułem informacji, a poza tym prosiłbym o jak najściślejszą dyskrecję, bo jednak z naszymi władzami w takich wypadkach nie ma żartów. Piękne czasy, w których musimy się wzajemnie prosić o dyskrecję! [...] my z żoną raczej jesteśmy zdecydowani postawić wszystko na jedną kartę, ale oczywiście bez jakiejś pomocy na pierwszy rok nie damy rady.

Przepraszam, że tak pana tym nudzę, ale rzeczywiście zaczyna się nam robić tak ciasno, że jednak trzeba coś zdecydować. Czy można liczyć na pomoc Rodzińskiego, Rubinsteina i innych? Bardzo byłbym wdzięczny gdyby Kochany Pan zechciał mnie w tym względzie poinformować. My w każdym razie zostaniemy tu 
do jakiegoś 5-go lutego, a będziemy się starać dłużej, jeżeli tylko przedłużą nam paszporty. Na razie odpoczywamy w cudnym Paryżu od ciężaru wschodniej Europy, a ja kończę „Requiem” poświęcone ofiarom wojny. Tak się pięknie złożyło, że chodzę pracować do pracowni Zyga Dygata's w Bibliotece Polskiej na Quai d'Orlean. Domyśla się Pan, że to całkiem niecodzienne przeżycie móc komponować w tych murach, tak przesiąkniętych na wylot „tamtą" Polską Wielkiej Emigracji!16

Odpowiedź Wierzyńskiego przychodzi bez zwłoki 13 stycznia 1947 roku, jest obszerna. Pojawia się w niej zestaw osób, które możemy śmiało zaliczyć do artystycznej konstelacji twórców emigracyjnych, dla których Ameryka okazała się głównie zoną bezpieczeństwa socjalnego i politycznego, rzadziej ziemią spektakularnego sukcesu; list kończy ostatni gorzki i zarazem paradoksalnie wybrzmiewający - w świetle przywołanych tu wielu nazwisk kolegów „,po fachu", zarówno twórców literatury, jak i kompozytorów, dyrygentów czy wykonawców-instrumentalistów - passus Wierzyńskiego: „,[nie ma w Ameryce] żadnej atmosfery, żadnych ludzi, żadnych przyjaciół...”. Są za to w liście Wierzyńskiego deklaracje i konkrety, sam jego autor wyraża pełne rozumienie dla wagi dylematów Palestra pragnącego pracować twórczo i w atmosferze pełnej wolności, niemożliwej do osiągnięcia - mimo osobistych i potwierdzonych sukcesów - w powojennej Polsce. Pisze doń:

\section{Kochany Panie Romanie,}

dziś otrzymałem Pana list z 9 bm., odpisuję natychmiast. Dziękuję Panu gorąco i z całego serca za oba listy, za Pana zaufanie i za to, co Pan pisze o Krzyżach i mieczach - a bardzo mnie to przejęło i wzruszyło. Żałowałem, że nie mogłem Panu odpisać w lecie. Pytałem ludzi, czy był Pan wtedy na koncercie Ficia ${ }^{17}$ w Paryżu, powiedziano mi, że nie dostał Pan wizy francuskiej. Rozu-

15 Zygmunt Dygat (1894-1977) - pianista, jeden z pięciu uczniów Ignacego Paderewskiego; koncertował za granicą w Europie i USA. Od 1920 roku zamieszkał w Paryżu, zajmując się pracą pedagogiczną; w czasie II wojny światowej uczestniczył w przerzutach do Anglii łączników i kurierów polskiego państwa podziemnego.

16 List Palestra do Wierzyńskiego z 9 I 1947 [zbiory nieopracowane, nr akcesji 7221/1-2 - Biblioteka Polska w Paryżu].

17 Chodzi o Grzegorza Fitelberga (1901-1964) - polskiego dyrygenta, skrzypka i kompozytora, ojca Jerzego Fitelberga. 
miem w pełni Pana intencje co do przyszłości i bardzo chciałbym, by zostały szybko i szczęśliwie zrealizowane. Nie potrzebuję Pana zapewniać, że gotów jestem zrobić wszystko co jest w mojej mocy, by Panu pomóc - niestety znając stosunki i Ficia wiem, że to będzie niedużo. Jeśli wolno mi się wtrącać do tych spraw, doradzałbym Panu przede wszystkim jak najściślejszą dyskrecję. Przed 5-ym lutym, nie da się definitywnie - jak myślę - wiele dokonać, dlatego niech Pan nie zrobi niczego, co mogłoby Panu utrudnić przedłużenie paszportu. Na miejscu zalecałbym się porozumieć jak najszybciej z Józefem Czapskim ${ }^{18}$, Hôtel Lambert. On wskaże innych ludzi i drogę. Gdyby Cz[apski] nie mógł Pana urządzić, (a przynajmniej jednocześnie) należałoby skierować staranie na Anglię. Panuje tam straszny bałagan, ale przebić się można. Najpoważniejszym „porucznikiem” jest moim zdaniem Tymon Terlecki ${ }^{19}$, z którym zdaje się Państwo mają kontakt. [...] Proszę do niego napisać, ja napiszę później, zaraz po tym liście. Może mógłby co zrobić w Paryżu Wła[dysław] Pobóg-Malinowski20 [...] z kt[órym] często koresponduję, może też Kajetan Morawski². Proszę to wybadać. Teraz co do Ameryki w związku z Panem. Po Polonii nie ma się czego spodziewać, przynajmniej na razie. Może z wiosną nastąpią pewne zmiany, ale to skomplikowany obraz i umieścić w nim Pana i kogokolwiek innego - niemożliwe. Rodziń[ski]. i Rubin[stein] - z pewnością pomocy nie odmówią, ale z innych sytuacji wiem, że skończy się ona na 100 lub 200 dol. Sprawy wizy emigracyjnej są niezmiernie zawiłe. Ja staram się od $1 \frac{1}{2}$ roku o wizę emigr. dla mego 7-letniego bratanka w Szwajcarii, sieroty po moim bracie zabitym przez Niemców w Majdanku, dziecko to może podpadać pod kategorię "sieroty wojennego" i „displaced person”, użyłem wszystkich dostępnych i niedostępnych wpływów, i protekcji, i wizy jeszcze nie mam. [...] Co innego jest z wizą turystyczną tzn. visitor's viza. O nią znacznie łatwiej, zwłaszcza przy protekcji. Na taką wizę przyjechał tu Zygmunt Dygat (zostanie tu do lutego), w tych

18 Józef Czapski (1896-1993) - malarz, pisarz, współpracownik „Kultury” Jerzego Giedroycia.

19 Tymon Terlecki (1905-2000) - krytyk literacki, eseista, teatrolog, redaktor „Polski Walczącej”, Literatury polskiej na Obczyźnie, wybitna postać polskiej emigracji w Londynie.

20 Władysław Pobóg-Malinowski (1899-1962) - oficer artylerii Wojska Polskiego, autor prac historycznych.

21 Kajetan Morawski (1892-1973) - dyplomata, polityk, działacz społeczny, publicysta, od września 1939 roku - poza Polską, po 1945 roku - emigrant polityczny. 
dniach ma audycję przed impresariem, spodziewa się kontraktu na przyszły rok [...]. Przyjeżdżając na wizę turystyczną można się tak urządzić, żeby zostać tu i poza jej trwaniem starać się o wizę emigr[acyjną], jest to jednak dość ryzykowne, nie mówiąc o tym, że trzeba mieć fundusze na pobyt. Wirtuoz ma tu, jak Pan wie, większe możliwości. Kompozytor jest w gorszej sytuacji. Ze znanych mi komp[ozytorów] ani Karol Rathaus ${ }^{22}$, ani Jerzy Fitelberg ani nawet przede wszystkim Strawiński nie mogą się utrzymać z wykonywanych utworów. Rathaus jest nauczyciel w Queens College. Fit[elberg] przepisuje nuty, co jest dobrze płatne, Straw[iński] pracuje w Hollywood. Życie kosztuje - b. skromnie licząc - 300-400 - dolarów miesięcznie na 2 osoby. Najlepiej powodzi się Kondrackiemu, który osiadł pod N. Jorkiem, w miejscowości Sea Cliff i daje lekcje fortepianu, jeżdżąc po okolicy do uczniów. Niech Pana nie zraża niepociągający obraz, postaram się pomówić z odpowiednimi ludźmi o sprawie pana przyjazdu (oczywiście sekretnie) - i dam Panu jeszcze znać. Do przygotowania takiej wyprawy trzeba czasu i starań, i jeszcze raz czasu i starań. Musi pan jakoś ten czas zdobyć. Dlatego myślę o Anglii. Czy może Pan przesłać tu swoje utwory symfoniczne? Dopilnuję tej sprawy u Rodzińskiego, z którym widuję się często. Proszę to zrobić jak najszybciej. [...]

O smaku tutejszego świata nie będę Wam pisał. Pisarz polski nie ma tu nic do roboty. Żadnej atmosfery, żadnych ludzi, żadnych przyjaciół. Muzyk ma oczywiście inne możliwości. Utrzymać się nam bardzo trudno. Ciągle wpadam z jednej ciężkiej sytuacji w drugą, co rozbija wszelką ciągłość pracy. Nigdy nie myślałem dotychczas o wyjeździe stąd, teraz dopiero takie myśli przychodzą mi do głowy - ale dokąd się wybrać? ${ }^{23}$

Od tego momentu trwa intensywna wymiana korespondencji. Do końca 1948 roku co najmniej jeden list miesięcznie wychodził spod pióra obu respondentów. Wierzyński stara się konsekwentnie poszukiwać kontaktów umożliwiających Barbarze i Romanowi Palestrom emigrację do Ameryki, informuje, choć lakonicznie, o własnej aktywności pisarskiej i towarzyskiej, z rzadka ,częstuje" melancholią... Z kolei listy Palestra są treściwe, miejscami nawet epickie,

22 Karol Rathaus (1895-1954) - kompozytor, pianista, pedagog, działacz polskich organizacji w USA.

23 List Wierzyńskiego do Palestra z 13 stycznia 1947 [Kolekcja Romana Palestra - BUW]. 
psychologizująco-autotematyczne; ciekawe poznawczo, zwłaszcza jako zapis dramatu sytuacyjnego twórcy związanego zawodowo z powojenną Polską i marzącego o ,innym pastwisku”. Dokumentalna ich waga jest więc nie do przecenienia: kreślone $\mathrm{z}$ pełną swobodą, funkcjonowały w obiegu pocztowym poza krajową cenzurą, wysyłane z miejsc czasowego pobytu Palestra na Zachodzie. Te z lat 1946-1947 i kilka z roku 1950 wyrażają dramat sytuacyjny kompozytora, który pragnie wejść na inną (własną) ścieżkę życia. Ta z kolei nieuchronnie prowadzi go do wielowymiarowej samotności, do - jak sam pisze - rozterek, jakie stały się udziałem „setek tysięcy istnień polskich”. Obrazują również niewesoły stan polskiej emigracji po wojnie, jej rozproszenie, porażenie, zagubienie...

Niewątpliwie zderzenie wyobrażenia o emigracji jako wielkiej moralnej i instytucjonalnej siły z praktyką życia po tzw. demokratycznej, drugiej stronie świata, było dla Palestra doświadczeniem niezwykle bolesnym. Głęboko przeżywa paradoksy polskie i osobiste, którymi dzieli się z Wierzyńskim w obszernych zapisach. Kolejne listy do 1950 roku pisane są w tym właśnie duchu. Oto kilka wyimków:

Kochany Panie Kazimierzu,

Jestem głęboko wzruszony Pańską uprzejmością i troskliwością, z jaką był Pan łaskaw zająć się moimi arcynudnymi sprawami. List Pański, wielokrotnie czytany i przetrawiony jest dla mnie, jak dotychczas, najlepszą informacją i najkonkretniejszym, najdokładniejszym obrazem smutnej rzeczywistości. Oczywiście, nie oczekiwałem cudów i raczej jestem nastawiony na dość ciężkie przeprawy zarówno materialne, jak moralne, ale przejmuje mnie najwięcej to poczucie jakiegoś zagubienia, zatopienia „w nicości” setek tysięcy istnień polskich. Przypuszczałem, że życie emigracji choćby najcięższe ma w sumie nie tylko jakieś znamię wielkości (w najbardziej romantycznym tego słowa znaczeniu), ale daje też maksimum realnych, konkretnych osiągnięć organizacyjnych. Konkretnie: zaproponowałem Czapskiemu, aby 2-gi korpus, który ma przecież za sobą piękną działalność wydawniczą zaczął także wydawać muzykę polską (mamy w tej sprawie niezłe propozycje także firm francuskich, które żądają jedynie zakupu pewnej ilości egzemplarzy), aby ruszyć jakoś z miejsca bardzo zabagnioną działalność muzyczną na emigracji, ale on niestety poza dobrymi, raczej nawet najlepszymi chęciami, nic w tej sprawie nie może zrobić, nie ma 
funduszy, nie ma możliwości i - jak się zdaje nie ma dla kogo. A to ostatnie oczywiście najsmutniejsze ze wszystkiego. Skierował mnie do Sakowskiego ${ }^{24}$; myślę, że w Londynie się zobaczę z nimi, ale nadziei nie mam wielkiej. Terleccy milczą od dość dawna, przy czym obiecali pewną dorywczą chwilową pomoc, za co im zresztą bardzo jestem wdzięczny ${ }^{25}$.

Albo:

My oczywiście w dalszym ciągu bardzo pragnęlibyśmy nie wracać do Polski i „zahaczyć" się albo tu, albo w Stanach. Na razie nasza sytuacja paryska jest o tyle pożałowania godna, że jesteśmy - oby tylko chwilowo - w ostatniej nędzy i w wielkiej „panice” finansowej, a nie wolno nam tego okazywać, bo wtedy przecież od razu mi powiedzą: „A czemuż Pan nie wraca do kraju, gdzie pan zawsze może z największą łatwością zarobić!" Sytuacja tragikomiczna, ale na dłuższą metę niemożliwa do utrzymania, a bardzo pragnęlibyśmy uniknąć powrotu do kraju².

Sprawa wyjazdu do USA powtarza się w liście następnym:

Chętnie wybrałbym się do Stanów choćby na jakiś czas, zwłaszcza że w Europie zachodniej sytuacja społeczna i polityczna pogarsza się w oczach. Jeździłem ostatnio do Kopenhagi na Festiwal Muzyczny i przy tej okazji przejeżdżałem po raz pierwszy po wojnie przez Kolonię, Bremę i Hamburg. To, co tam zobaczyłem było ciężkie nawet dla Warszawiaka, który [nie ma] specjalnych powodów wzruszać się losem Niemiec. Wleźliśmy w jakąś ciemną i ponurą epokę, w której to wszystko co robimy, traci coraz bardziej jakikolwiek sens. Ale zresztą nie ma co o tym pisać - może kiedyś będziemy mogli pomówić o tych sprawach osobiście? ${ }^{27}$

24 Juliusz Sakowski (1904-1977) - polski dyplomata, po wojnie wydawca, felietonista, krytyk literaki, eseista.

25 List Palestra do Wierzyńskiego z 3 II 1947 [zbiory nieopracowane, nr akcesji 7221/1-2 - Biblioteka Polska w Paryżu].

26 List Palestra do Wierzyńskiego z 11 V 1947 [tamże].

27 List Palestra do Wierzyńskiego z 6 VI 1947 [tamże]. 
O ile Wierzyński, jakkolwiek oswojony ze swoją trwającą kilka lat emigracją, również wolny od przeżyć okupacyjnych, pisze listy rzeczowe, pragmatyczne, stonowane emocjonalnie, o tyle w korespondencji Palestra diapazon emocji rośnie z każdym miesiącem 1947 roku, zapowiadając decyzję, którą kompozytor podejmie w roku 1949, bezpośrednio po Zjeździe Kompozytorów i Krytyków Muzycznych w Łagowie Lubuskim ${ }^{28}$. Postawi przysłowiową kropkę nad „i”, opuści kraj z zamiarem pozostania na stałe w jakimś zachodnim znośnym „miejscu postoju”. Zanim jednak tak się stanie, stara się o służbowe wyjazdy do Paryża - o wytchnienie po wyrwaniu się z krajowego piekła. Ciekawe, że o Polsce - jeszcze nie jako rzeczywisty, ale już mentalny emigrant pisze - „tam”:

Nareszcie znów jestem w Paryżu i to mocno zmęczony pobytem w Polsce! Rzeczywiście tempo życia mają tam diabelne, i człowiek "odwykłszy” w głowę zachodzi, po co tam wszyscy tak harują od rana do nocy. Ludzie są tak "zaganiani”, tyle mają roboty, tyle "organizują" i odbudowują, że chwilami człowiekowi przykro się robi, że na to wszystko "trochę" krytycznie patrzy. W każdym razie zryw tam jest duży i zewnętrznych tj. czysto wegetacyjnych trudności życiowych mniej niż w innych krajach Europy. Co za bogaty kraj, w którym - mimo wszystko - jest materialnie lepiej niż gdzie indziej!

Oczywiście będziemy jednak [starać się] za wszelką cenę zostać tutaj lub co byłoby oczywiście lepsze - przyjechać do Stanów. Stwierdzenie dosyć dziwne po tamtym wstępie - ale Kochany Pan mnie rozumie bez trudu, prawda? Tak to już jest niewesoło! Niestety to "pozostanie” po tej stronie zależy też w dużej mierze od możliwości utrzymania się tu, a z tym jest bardzo trudno. Ostatecznie jakoś sobie od biedy dajemy radę, ale w rezultacie przy takim życiu z tygodnia na tydzień ciągle staje przed nami ewentualność konieczności powrotu do kraju, gdy tylko jakakolwiek z dorywczych prac finansowych nie wypali. Dlatego nie mogę wykluczyć ewentualności powrotu do Polski ze względów czysto material-

$28 \mathrm{Na}$ Zjeździe proklamowano socrealizm w sztuce $\mathrm{i}$ wzmocniono procesy ją centralizujące. Palester odnosi się do sytuacji krajowego twórcy w wielu szkicach, najdobitniej jednak wybrzmiewa jego argumentacja w Konflikcie Marsjasza („Kultura”/Paryż 1951, nr 7-8), Uwagach o muzyce („,Kultura”/Paryż 1951, nr 12). Zob. także V. Wejs-Milewska, Marsjaszowe konflikty. O szkicach Romana Palestra, Do publiczności w Polsce: Miłosz, Palester, Panufnik, [w:] tejże, Wykluczeni - wychodźstwo, kraj. Studia z antropologii emigracji polskiej XX wieku (idee, osobowości, instytucje), Białystok 2012, s. 43-144. 
nych, zdając sobie zresztą całkowicie sprawę z całego tragizmu i beznadziejności takiego powrotu ${ }^{29}$.

Wierzyński dopytuje, chce zrozumieć na czym w istocie polega paradoks sytuacyjny Palestra w kraju:

Niezmiernie to przykre, że był Pan w Polsce. Proszę napisać mi coś bliższego o tym, z kim się Pan spotkał, co myślą i mówią, na czym polega ten „zapał” organizacyjny, a na czym Pana sceptycyzm? ${ }^{30}$

Nie znamy odpowiedzi Palestra - prawdopodobnie już nie odpisał. Zachował się za to jedynie list Wierzyńskiego datowany na 28 marca 1948 roku ${ }^{31}$, którego treść dotyczy propozycji nawiązania nowych kontaktów z filharmonikami amerykańskimi, a jego poetyka zdaje się też potwierdzać długą przerwę w korespondencji. Dopiero obszerny list Palestra z 9 sierpnia 1950 roku wyjaśnia wiele: jego kondycja jako kompozytora i Polaka, który w 1949 roku opuścił kraj, a właściwie z kolejnej podróży służbowej do Paryża już do kraju nie powrócił, co znaczy „wybrał wolność”, jest nie do pozazdroszczenia. Nie należy do żadnego z dwu światów - na Zachodzie w środowisku europejskich kompozytorów i muzyków spotyka się z krytyką swojej decyzji, staje się dla nich konkurentem, w PRL-u zaś - dotyka go boleśnie anatema i odcięcie od środków finansowych. „Pełna samotność”, o której tu i ówdzie mowa w listach, staje się faktem, choć i pojawia się nadzieja. List do Wierzyńskiego jest więc kolejnym wołaniem o pomoc do starszego i okrzepłego w życiu poza Polską kolegi, do druha w nieszczęściu:

\section{Kochany Panie Kazimierzu!}

dawno, bardzo dawno nie pisałem do Pana, ale w ciągu tych dwóch lat tyle rozmaitych rzeczy działo się z nami, że przypuszczam, że nie weźmie mi Pan za

29 List Palestra do Wierzyńskiego z 28 września 1947 [zbiory nieopracowane, nr akcesji 7221/1-2 - Biblioteka Polska w Paryżu].

30 List Wierzyńskiego do Palestra z 15 października 1947 [Kolekcja Romana Palestra - BUW].

31 List Wierzyńskiego do Palestra z 28 marca 1948 [tamże]. 
złe milczenia, które zresztą nie znaczyło, abyśmy często nie mówili o Państwu... A jeżeli nie pisałem, to po prostu dlatego, że człowiek był i jest tak „zagoniony” w codziennej harówce, że każdą minutę wolną wykorzystuje raczej dla komponowania, aniżeli do dzielenia się z rodakami nowinami, które z reguły i zawsze są jak najgorsze!

Przez cały ten czas, tj. od początku 1947-go roku udało się nam obojgu przetrwać w Paryżu, co prawda w sposób, który zbyt często już graniczył ze skrajną nędzą, ale ostatecznie udało się przetrwać i artystycznie ten okres był dla mnie bardzo korzystny. Na skutek nacisku moich kolegów krajowych i z porady pewnych „emigrantów” nie zrywałem początkowo z krajem, ale oczywiście nie mogłem wiecznie wytrzymać w tej sytuacji i w ciągu bieżącego roku definitywnie zerwałem wszystkie stosunki. Wydawało mi się, że względy koleżeńskie odpadły wobec faktu, że i tak tam już żaden z moich kolegów nie wyjeżdża za granicę tzn. na Zachód. A poza tym odbywa się teraz tak planowe i tak konsekwentne „wykańczanie” tego wszystkiego cośmy do niedawna uważali za najpiękniejsze cechy kultury polskiej, że wydaje mi się, że trzeba zacząć jakiś wielki krzyk w tych sprawach. Niestety pisma nasze emigracyjne nie zdają się doceniać tej straszliwej sytuacji, która jest montowana tak niesłychanie zgrabnie, że jeśli potrwa lat kilkanaście to po prostu nie trzeba będzie nic "włączać" do ZSRR, bo i tak wtedy Polacy w Polsce przestaną "być Polakami” w sensie jakiejś elementarnej odrębności kulturalnej. Jeśli chodzi o Pana, to czuję, że piszę to niepotrzebnie, bo Pan zapewne zdaje sobie jasno sprawę z tej sytuacji, ale tysiące ludzi żyje w zupełnej nieświadomości tego, co się dzieje i - na rany boskie - trzeba robić coś w tej sprawie.

Nie jestem tutaj związany specjalnie z żadnym stronnictwem politycznym, widuję ludzi i spod znaku londyńskiego i spod znaku Mikołajczyka, ale i u tych i tamtych jest tak duży prymat zagadnień czysto politycznych, że nie spotkałem się z dostatecznym zrozumieniem dla spraw, które politykom zdają się drugorzędne, a które przecież w istocie są sprawami życia i śmierci, i to już nie tylko nawet dla samych Polaków!

Chciałem pisać do Pana w moich sprawach osobistych, a rozpisałem się o sprawach, które i tak Panu pewno są dobrze wiadome! Więc, wracając do moich spraw: w odpowiedzi na moją postawę zabroniono w Polsce grania mojej muzyki, unieważniono moje kontrakty z wydawcą i zostałem zakwalifikowany jako „formalista” muzyczny o „orientacji zachodniej”. Uderzenie jest o tyle 
mocne, że wydawcom nie będzie wolno nawet wypożyczać mojej muzyki za pieniądze za granicą, więc w ten sposób ilość wykonań moich tu na Zachodzie ograniczy się tylko do tego, co tu posiadam (a w ostatnich latach miałem sporo wykonań w Zachodniej Europie). Oprócz tego ZAiKS przestał mi wypłacać moje należności autorskie, z których dotychczas głównie żyłem, przy jednoczesnej odmowie (a raczej braku odpowiedzi, co wychodzi na jedno) zwolnienia mnie z członkostwa tego związku. W tym stanie rzeczy nawet te drobne sumy, które wpływają do tutejszych związków autorskich za publiczne wykonania (nie mówiąc o dochodach z filmów, które są znacznie większe) mojej muzyki są i będą w dalszym ciągu odsyłane przez te związki do Polski, do ZAiKS-u.

Wytrwałem jeszcze tych kilka ostatnich miesięcy sam nie wiem jakim cudem, ale teraz już „wszystko się kończy” i po prostu absolutnie nie wiem, co dalej robić. Ani żona (w dodatku chora), ani ja nie możemy znaleźć tutaj żadnej pracy, bo jak Pan wie, przyjaźń i życzliwość francuska kończy się w momencie, kiedy człowiek czegoś potrzebuje. Zresztą szereg ludzi obiecuje mi już od roku z górą pracę, a to w północnej, a to znów w południowej Ameryce, ale nic z tego wszystkiego nie wychodzi i kończy się na życzliwych obietnicach, z których jak wiadomo, nie można wyżyć 32 .

Po raz pierwszy w liście z 1950 roku pojawia się instytucja, z którą zarówno Wierzyński, jak i Palester związani będą przez wiele lat: mowa o radiu; współpraca z nim poety będzie trwała dziewiętnaście lat, kompozytora - dwadzieścia. Obaj się jeszcze wówczas tego, kiedy do siebie piszą nie spodziewają, że ta instytucja połączy ich obu, a nawet że Palester jako kierownik działu kulturalnego, a więc niejako przełożony freelancerów, będzie miał wpływ na treść wystąpień Wierzyńskiego przed mikrofonem RWE. Pełen niepokoju i zarazem nadziei poniższy fragment listu powstaje na rok przed pierwszą publiczną wypowiedzią autora Wisty o powodach zerwania z Polską ${ }^{33}$.

Zdawał sobie już wtedy sprawę Palester z wagi swojego położenia niejako „między światami” i ze specyficznej natury doświadczenia, wynikłego

32 List Palestra do Wierzyńskiego z 9 VIII 1950 [zbiory nieopracowane, nr akcesji 7221/1-2 - Biblioteka Polska w Paryżu].

33 Zob. List otwarty do kompozytorów krajowych - audycja BBC z 1 grudnia 1951 [skrypt: Kolekcja Romana Palestra-BUW]. 
z udziału w życiu kulturalnym pierwszych lat powojennej Polski i znaczenia tego faktu dla polityki medialnej amerykańskiej instytucji. Celnie przeczuwał też rolę, jaka miała mu w niej przypaść. Ani na jotę się nie pomylił:

W tej sytuacji, którą już trudno nazwać „życiem” dowiedziałem się o powstaniu komitetu „Free Europe”, którego celem podobno ma być też między innymi pomoc dla „uciekinierów” zza żelaznej kurtyny. Niestety nigdzie tutaj nie mogę się nic dokładniejszego o tym komitecie dowiedzieć, tak że nawet zameldowałem się z wizytą do attaché kulturalnego USA, którego mam zobaczyć w przyszłym tygodniu, aby od niego dowiedzieć się przynajmniej adresu tego komitetu. Ja nie chcę „pomocy” w sensie zapomogi pieniężnej i byłoby mi wstyd przyjmować ją i nie dawać nic w zamian, ale chciałem zaproponować moją współpracę np. przy emisjach radiowych stacji Free Europe, którą od kilku dni tu słyszymy, a w której mógłbym się naprawdę przydać i to nie tylko muzycznie. Jestem jednym z nielicznych, niestety bardzo nielicznych artystów, którzy "urwali się" po przebywaniu jakiś czas w sowieckiej Polsce i stąd nie tylko wiem mnóstwo rzeczy, ale i orientuję się trochę w psychice ludzkiej, jaka się tam wytworzyła. Oczywiście po kilku dniach działalności nie chcę i nie mogę wydawać sądu o działalności sekcji polskiej stacji Free Europe, ale wydaje mi się, że mnóstwa rzeczy tam brakuje z jednej strony, a „atak” polityczny jest nie zawsze właściwie skierowany. Ale to zresztą dalsza sprawa ${ }^{34}$.

Kolejne listy datowane są już na rok 1955 i lata następne, powoli wprowadzają w nowe wątki, zbliżają nas do różnych warsztatów pracy respondentów. Nie towarzyszy im też pośpiech, tak charakterystyczny dla korespondencji Wierzyńskiego, z kolei niepokoje Palestra nakierowane będą bardziej na pracę własną - kompozytorską i publicystyczną, dlatego pobrzmiewać w nich będzie niejednokrotnie spokojna, miejscami melancholijna myśl. Obaj z biegiem czasu będą umacniać się w swojej wielkiej samotności, szyfrować ją, obu nie dany będzie powrót do Polski takiej, jaką znali i przenieśli we wspomnieniach na „drugą stronę świata” przedzielonego żelazną kurtyną.

34 List Palestra do Wierzyńskiego z 9 VIII 1950 [zbiory nieopracowane, nr akcesji 7221/1-2 - Biblioteka Polska w Paryżu]. 
Już ten mały „kęs” korpusu epistolarnego powiązanych ze sobą pasją słowa i dźwięku autorów nieunikających wyrazistych deklaracji i kontrowersyjnych ocen stanowić winien interesującą zachętę do lektury całości, zarazem jest także dowodem na istnienie mało znanej relacji dwu ważnych postaci polskiej kultury XX wieku. Warto ją zgłębiać nie tylko przy okazji niedawno minionej 50. rocznicy śmierci Poety, jak również 30. rocznicy śmierci Kompozytora.

\section{Bibliografia}

Helman Z., Roman Palester. Twórczość i dzieło, Kraków 1999.

Listy Kazimierza Wierzyńskiego do Józefa Wittlina, „Więź” 1989, nr 2.

Palester R., Konflikt Marsjasza, „Kultura”/Paryż 1951, nr 7-8.

Palester R., Słuch absolutny. Niedokończona autobiografia i listy z lat wojny, oprac. i komentarzami opatrzyła Z. Helman, Warszawa-Kraków 2017.

Palester R., Uwagi o muzyce, „Kultura”/Paryż 1951, nr 12.

Wejs-Milewska V., Marsjaszowe konflikty. O szkicach Romana Palestra, Do publiczności w Polsce: Miłosz, Palester, Panufnik, [w:] tejże, Wykluczeni - wychodźstwo, kraj. Studia z antropologii emigracji polskiej XX wieku (idee, osobowości, instytucje), Białystok 2012, s. 43-144.

Wierzyński K., Listy 1941-1956, Warszawa 2016.

\section{Archiwalia}

Kolekcja Romana Palestra (Gabinet Zbiorów Muzycznych - BUW).

Korespondencja Kazimierza Wierzyńskiego (Biblioteka Polska w Londynie, Biblioteka Polska w Paryżu). 